\title{
Small ruminant fattening practices in Amhara region, Ethiopia
}

Shewangzaw Addisu Mekuria ${ }^{1 *}$, Aschalew Assefa Teshager ${ }^{1}$, Addis Getu Endeshaw ${ }^{1}$, Malede Birhan Atinaw ${ }^{1}$ and Assemu Tesfa Sendeku ${ }^{2}$

\begin{abstract}
Background: In Ethiopia, small ruminant had a great role in the economic development for farmers or producers, food-insecure areas and one of the main sources of meat production. The study was conducted in five small ruminant potential zones of Amhara region from November to June, 2017, with the objective of assessing small ruminant fattening practices in Amhara region, Ethiopia. Twenty representative kebeles were selected purposively. From each of selected kebeles, 10 small ruminant fatteners were selected purposively based on their fattening experience. A total of 200 households were selected for interviewing. Data were analyzed by using SPSS version, 20.
\end{abstract}

Results: Majority of (47\%) small ruminant fatteners can read and write. Mean and SD of family size per household was shown to be $5.22 \pm 2.00$. Mean and SD of private and communal grazing lands and total land for traction was $0.30 \pm 0.60,0.81 \pm 1.81$ and $1.84 \pm 2.90$, respectively. From the total of $100 \%$ respondents only $46.6 \%$ had there owen private grazing land this mean the remaining $53.4 \%$ were utilizing communal grazing land. Among the $46.6 \%$ of respondents only $74.5 \%$ were primarily grazed fattening animals. About $59 \%$ of respondents responded that the status of grazing land was decreased from the previous status, but the remaining 31.5 and $9.5 \%$ responded that there was no change and that it was increasing, respectively. Mean and SD of sheep and goat fattening per household was $2.86 \pm 2.90$ and $1.65 \pm 4.67$, respectively. Majority (71.5\%) of producers preferred fattening sheep species to goat. In Amhara region, the purpose of small ruminant fattening was mainly income source (81.5\%) and the remaining 12,2 , $1.5,1,1$, and $1 \%$ were risk/benefit, meat, social or cultural function, sacrifices/rituals, saving and others, respectively. Natural pasture grazing and stubble grazing were the major feed sources in the wet and dry seasons, respectively. Fatteners were provided with supplementary feeds for small ruminant fattening twice a day (36\%), once in a day (31\%) and whenever available (12\%). Majority of respondents (77.6\%) were not provided with supplementary feed scientifcally recommended due to the low supply and high cost of concentrate feed in the market. The main water source was pipe water. The average distance of water from their home was less than one $\mathrm{km}$, and watering frequency was twice a day.

Conclusions: In general, the present study showed that fatteners in the region did not fatten small ruminants scientifically recommended, because there were high cost of supplementary feed in the market and lack of enfaces on the development of small ruminant fattening in Amhara region. So, there should be given more enfaces by the government and researches should be done on alternative and non-conventional feeds with low price by considering the export standard of meat production.

Keywords: Amhara region, Fattening, Feed, Purpose, Small ruminant

\footnotetext{
*Correspondence: shewakibr12@gmail.com

${ }^{1}$ University of Gondar, P.O. Box 196, Gondar, Ethiopia

Full list of author information is available at the end of the article
} 


\section{Background}

Small ruminants are important components of the livestock subsector and are sources of cash income and play a vital role as sources of meat, milk and wool for smallholder keepers in different farming systems and agroecological zones of the country. They are also sources of foreign currency [2]. Sheep and goat in Ethiopia and most developing regions are kept under traditional extensive systems. Sheep and goats are largely produced in mixed crop-livestock, specialized pastoral and agro-pastoral systems. Livestock production is of subsistence nature. Market-oriented or commercial production is almost nonexistent [10].

According to the report of [8], the total annual meat production comes from cattle (63\%), sheep (25\%) and goats $(12 \%)$. At the national level, sheep and goat account for about $90 \%$ of the live animal/meat and $92 \%$ of skin and hide [8] export trade value. In the lowlands, sheep with other livestock are the mainstay of the pastoral livelihoods.

In traditional production systems, small ruminants provide both tangible benefits such as cash income from animal sales, meat for home consumption, manure, fiber and skins and intangible benefits such as savings and insurance against emergencies, employment, cultural and ceremonial purposes [6]. Thus, small ruminants contribute their share in fundamental issues related to reducing under-nutrition, enhancing food security, combating rural poverty and achieving rates and patterns of agricultural growth that would contribute to the overall economic development and environmental protection [9].

Ethiopia has some important comparative advantages in the Middle Eastern livestock and meat markets. Live animal exports are high, as an estimated 1.6 million livestock [1]. However, feed shortages are often highlighted as a constraint to Ethiopia's livestock and meat industry [12].

Live animal exports contributed $70 \%$ of the earnings, while $30 \%$ was obtained from meat exports. However, the lack of exporting routes and ports, illegal live animal trade, the shortage of live animals and the lack of appropriate breeding programs are some of the main challenges faced by the sector. The presence of large livestock population with diverse and adaptable genotypes, and diverse agroecologies for production of different types of livestock; the expansion of agro-industries and the increase of by-product feedstuffs allowing for enhanced productivity; proximity to Middle East countries; high demand for meat and live animals in the market including the domestic market are some of the opportunities that the sectors have [7]. However, based on the above facts there was no documented information in order to improve and know the status of small ruminant fattening in Amhara region. Thus, on the basis of this background this study was initiated with the objective of small ruminant fattening practices in Amhara region.

\section{Methods \\ Description of the study area}

The study was conducted in five parts of Amhara regional zones of (N/Gondar, S/Gondar, S/Wollo, W/Gojjam and N/Shewa). The Amhara region has 105 woredas. According to figures of the Central Statistical Agency [3], the region has an estimated total human population of $19,120,000$, consisting of 9,555,000 males and 9,565,000 females. About $16,925,000$ or $88.5 \%$ of the population are rural inhabitants, while $2,195,000$ or $11.5 \%$ are urban. The annual population growth rate is $2.7 \%$. With an estimated area of $159,173.66 \mathrm{~km}^{2}$, the region has an estimated density of 120 persons $/ \mathrm{km}^{2}$. The Amhara region is the second most densely populated region in Ethiopia. Some $18-20 \%$ of the region's population is critically food insecure. The livestock population in Amhara region includes cattle $(14,710,911)$, sheep $(10,024,277)$, goats $(6,064,944)$, horses $(420,760)$, mules $(157,213)$, donkeys $(2,677,429)$, camels $(66,364)$, poultry $(18,031,121)$ and beehives $(1,361,329)$. Mutton and chevon household consumption, sale, wages in kind and others utilization-private peasant holders in Amhara region were 94.15, 1.87, 0.23 and 3.74\%, respectively [4] (Fig. 1).

\section{Sampling design, techniques and procedures}

From the total of the selected five zones of Amhara region, a total of 20 kebeles were selected. Each zone was stratified by midland and low land agroecology zones and then from each midland and low land agroecology zones one potential woreda was selected purposively. From the selected district, two kebeles were selected randomly. Then, from each of selected kebeles, ten small ruminant fatteners were selected purposively for data collection. Therefore, a total of two hundred households were selected.

\section{Data requirements, sources and methods of data collection} Both primary and secondary sources of data were used to obtain qualitative and quantitative data by structured and semi-structured questioner. Primary data such as grazing land, feed sources and feeding, water sources and watering of small ruminant were generated from interviewed respondents, and secondary sources that covered households' demographic characteristics, institutional settings were obtained from District Agricultural Rural Development and Livestock Agency office. 


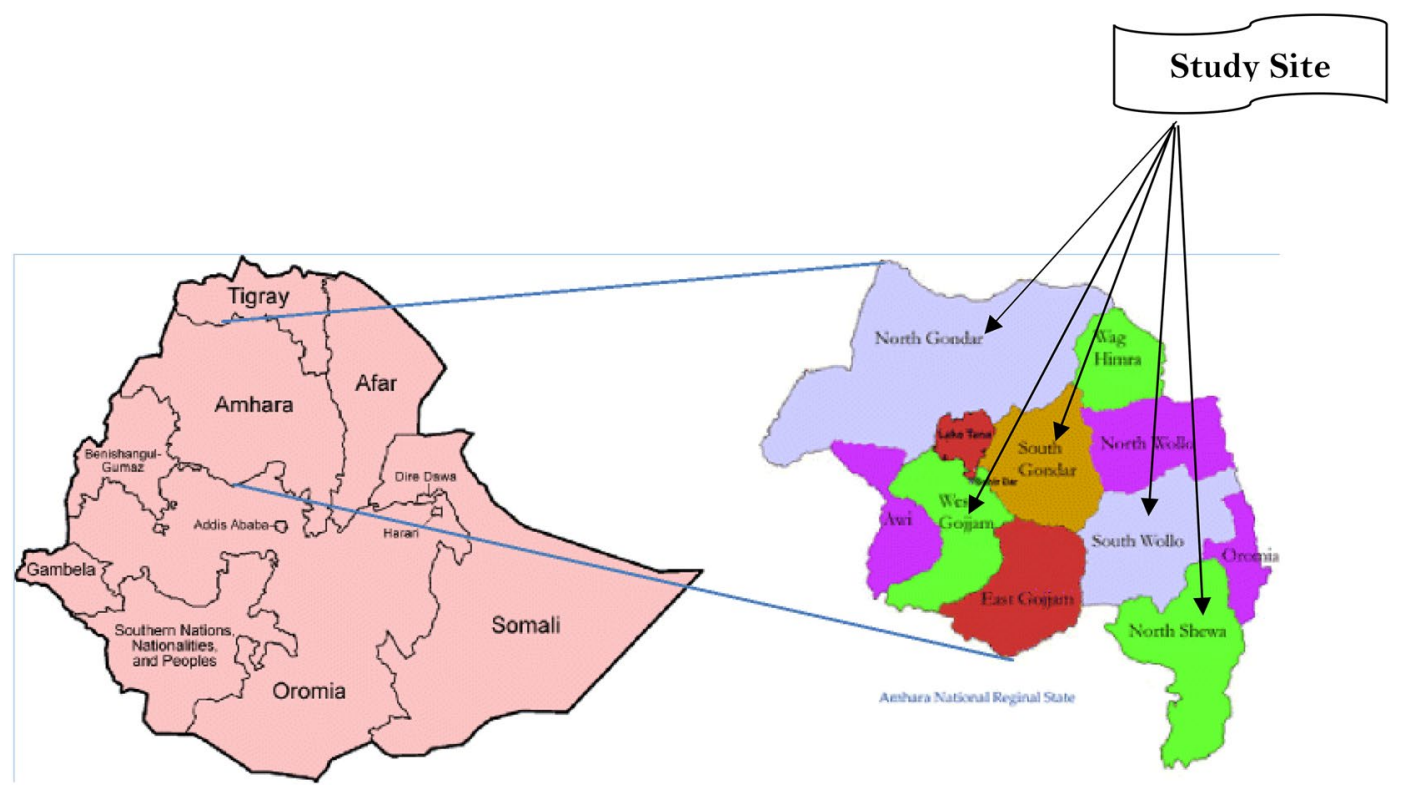

Fig. 1 Study map of Amhara region

\section{Data analysis}

The collected data were directly entered and analyzed by Statistical Package for Social Sciences (SPSS) version 20 software.

\section{Results and discussion}

Socioeconomic characteristics of households in the study area

The characteristics of households in the study area of Amhara region are presented in Fig. 2. From the total of

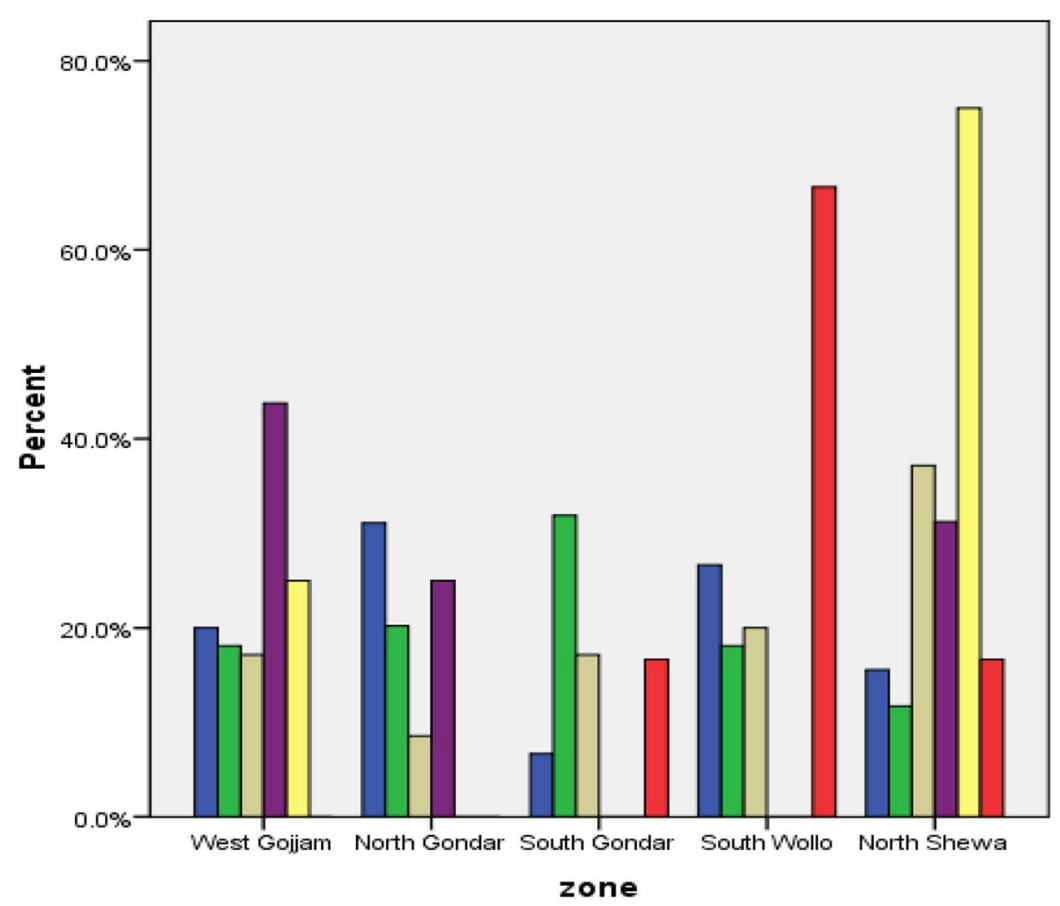

Educational Status $\square$ illitrate

$\square$ read and write

Elementary School

Secondary school

Above high school

religious Education

Fig. 2 Educational status of household in the study area 
Table 1 Average household family size in the study area

\begin{tabular}{lll}
\hline Household & Mean & SD \\
\hline Total family size & 5.22 & 2.00 \\
Male & 2.65 & 1.38 \\
Female & 2.55 & 1.26 \\
\hline
\end{tabular}

Table 2 Mean and SD of private, communal and total lands for grazing and traction purpose in hectare in the study area

\begin{tabular}{lccrc}
\hline Land description per ha & $\boldsymbol{N}$ & Min & Max & Mean \pm SD \\
\hline Private grazing land & 200 & 0.00 & 4.00 & $0.30 \pm 0.61$ \\
Communal grazing land & 200 & 0.00 & 20.00 & $0.81 \pm 1.81$ \\
Total land for traction & 200 & 0.00 & 21.00 & $1.84 \pm 2.90$ \\
\hline
\end{tabular}

$(N=200)$ respondents, majority of small ruminant fatteners can read and write (47\%), while the remaining $22.5,17.5,8.0$, 2.0 and $3.0 \%$ were illiterate, elementary school, secondary school, above high school and religious education, respectively. Educational status of zones showed that in West Gojjam majority of fatteners were secondary school, whereas in North Gondar, South Gondar, South Wollo and North Shewa they are illiterate, can read and write, are religiously educated and had above high school, respectively. Mean and standard deviation (SD) of family size per household in the study area was $5.22 \pm 2.00$, and that of females and males was $2.65 \pm 1.38$ and $2.55 \pm 1.26$, respectively (Table 1 ).

\section{Grazing land utilization}

Mean and SD of private, communal and total lands for grazing and traction purpose in the study area is shown in Table 2. In the region, the mean and SD of private grazing land for fattening purpose was $0.30 \pm 0.61$ ha and that of communal grazing land of its mean and SD were $0.81 \pm 1.81$ ha. Generally, the mean and SD of total land for traction was shown to be $1.84 \pm 2.90$ ha.

The mean and standard deviation of private grazing land in the present study was almost in line with that in the study of [5], i.e., $0.22 \pm 0.01$. However, the mean and standard deviation of land for traction did not agree with that in this study, i.e., $1.08 \pm 0.04$. This may be due to the presence of large size of land per household in the low land area of Amhara region.

\section{Private grazing land utilization}

Utilization of private grazing land for fattening in the study area is indicated in Fig. 3. From the total of $100 \%$ respondents only $46.6 \%$ had there owen private grazing land this mean the remaining $53.4 \%$ were utilizing communal grazing land. Among the $46.6 \%$ of respondents only $74.5 \%$ were primarily grazed fattening animals

The results were in line with the study of [13] who reported that the land-owning people who have private grazing lands (29\%) to feed and supplement their animals during feed scarcity periods (during the rainy season). However, the average area of private grazing lands was very small as compared to the present study which was 0.04 ha per household.

\section{Status of private and communal grazing land}

Status of grazing land in the study area is indicated in Table 3. Even though the respondents had private and communal grazing lands in the study zones, 59\% responded that the status of grazing land was decreasing from time to time, whereas $9.5 \%$ responded that it was
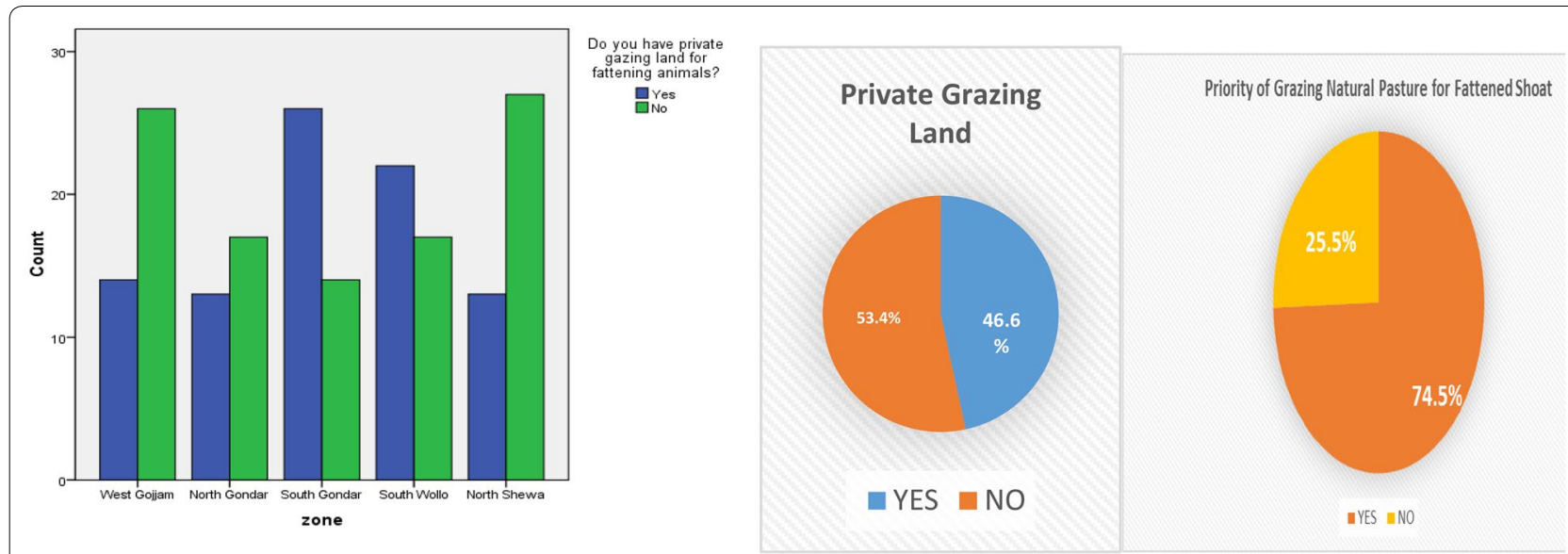

Fig. 3 Utilization of private grazing land for fattening 
Table 3 Status of grazing land in the study area

\begin{tabular}{lcr}
\hline Grazing land status & Frequency & $\%$ \\
\hline Decreasing & 118 & 59.0 \\
Increasing & 19 & 9.5 \\
No change & 63 & 31.5 \\
Total & 200 & 100.0
\end{tabular}

Table 4 Maximum, mean and SD of small ruminant fattening per individual in the study area

\begin{tabular}{llll}
\hline $\begin{array}{l}\text { Sheep and goat } \\
\text { population }\end{array}$ & Max & Mean & SD \\
\hline Sheep Ewe & 69.00 & 5.1800 & 8.57703 \\
Sheep Ram & 17.00 & 1.6050 & 2.53002 \\
Sheep Lamb & 28.00 & 2.9200 & 3.93331 \\
Sheep fattening & 19.00 & 2.8600 & 2.90042 \\
Goat Doe & 80.00 & 3.5050 & 9.72176 \\
Goat Buck & 22.00 & 1.0450 & 2.76063 \\
Goat Kid & 32.00 & 2.0200 & 4.82764 \\
Goat fattening & 50.00 & 1.6450 & 4.66129 \\
\hline
\end{tabular}

increasing and the remaining $31.5 \%$ responded that there was no change.

The size of land decrease may be due to an increment of human population from time to time which was the land utilized for human food crops, expansion of urban and cities, utilization of communal grazing land for public service such as school, health center, and construction of offices for different sectors and for investment purpose.

\section{Small ruminant fattening per household}

Maximum, mean and SD of small ruminant fattening per household in the study area are indicated in Table 4 . In Amhara region, there was a good potential of keeping small ruminant population per individual or per household. The mean and SD of Sheep Ewe, Ram and Lamb population was shown to be $5.18 \pm 8.58,1.61 \pm 2.53$ and $2.92 \pm 3.93$, respectively. From these an average of 2.86 sheep were used for the purpose of fattening. In addition to this, the average population of Goat Doe, Goat Buck and Goat Kid was shown to be $3.51 \pm 9.72,1.05 \pm 2.76$ and $2.02 \pm 4.83$, respectively, of which an average of 1.65 were used for the purpose of fattening. Generally, according to the report of the respondents in the study areas there were involved in sheep keeping than goat per household for fattening. This might be due to the presence of suitable climatic condition and more preference of the community for mutton in the study region than chevon.

Standard deviation of sheep fattening in the study area was almost in line with that in the study of [13], which was 2.46 .

\section{Preferred small ruminant species for fattening}

Small ruminants selected for fattening purpose in the study zones are indicated in Fig. 4. The result showed that in West Gojjam the households selected sheep for fattening than goats, in north Gondar both sheep and goat were preferred or selected for fattening, but the figure shows that the fatteners were mostly involved in goat fattening than sheep fattening, which might be due to the climatic condition of the area which was suitable for goat production than sheep, in south Gondar producers were involved in both goat and sheep fattening, in South Wollo
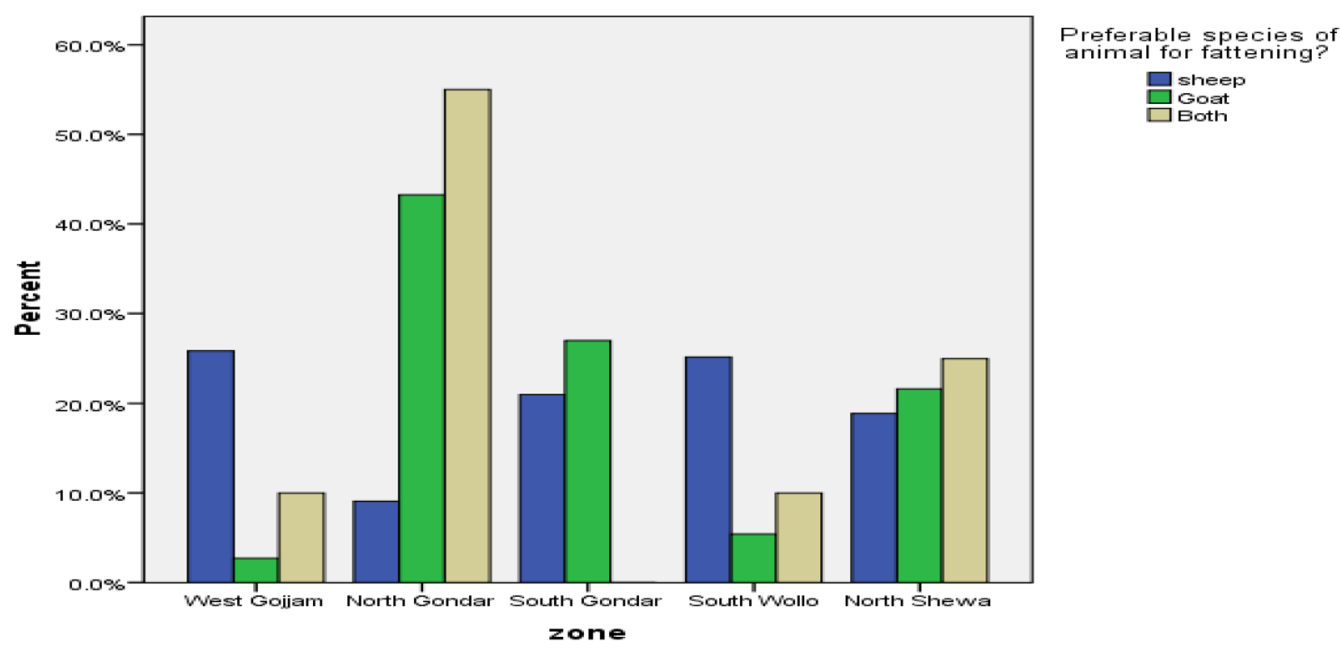

Fig. 4 Small ruminant selected for fattening in the study zones of Amhara region 
majority of producers were involved in sheep fattening and in North Shewa they were almost similarly involved in sheep and goat fattening. Generally, small ruminants selected for fattening in the region (Table 5) showed that $71.5 \%$ of producers were involved in sheep fattening than goat fattening.

\section{Purpose of sheep and goat fattening in the study areas}

The purpose of keeping sheep and goat (small ruminant) fattening in the study area is indicated in Fig. 5. According to the respondents of west Gojjam zone, the purpose of fattening small ruminants was income sources, meat, sacrifice/rituals, saving and risk benefit, whereas in North Gondar, South Gondar, South Wollo and North Shewa the major purpose of fattening small ruminants was meat and saving, all, saving, sacrifice/ rituals, respectively. However, generally in Amhara region producers fattened small ruminants for the purpose of income. In addition to this, the purpose of small ruminant fattening in the Amhara region (Table 6) indicated that in Amhara region producers were involved in small ruminant fattening for the purpose of income source, meat, sacrifice/rituals, social/cultural function,

Table 5 Small ruminants selected for fattening in Amhara region

\begin{tabular}{lcc}
\hline Species of animals & Frequency & $\%$ \\
\hline Sheep & 143 & 71.5 \\
Goat & 37 & 18.5 \\
Both & 20 & 10.0 \\
Total & 200 & 100.0 \\
\hline
\end{tabular}

saving, risk/benefit and others which were 81.5, 2.0, 1.0, $1.5,1.0,12.0$ and $1.0 \%$, respectively.

The present study agreed with the study of [10]. Farmers were keeping sheep and goats for the purpose of income source in the area of Fogera, Alaba, Metema, Mieso, Goma and Alamata. However, according to their study in Dale and Bure they kept small ruminants primarily for saving and meat (home consumption), respectively. It was also in line with the finding of [5] in Oromia region of Ilu Aba bora zone who pointed out that the purpose of keeping small ruminants was primarily income generation.

\section{Small ruminants feed sources and supplementary feeds}

The major feed sources in the dry and wet seasons for small ruminants in the study area are shown in Table 7 . According to the respondents, the first feed source which was utilized for fattening small ruminant was natural pasture, whereas in the dry season stubble grazing. The feeding practices of fattening small ruminant in the study

\begin{tabular}{|c|c|c|}
\hline Purpose/reasons & Frequency & $\%$ \\
\hline Income source & 163 & 81.5 \\
\hline Meat & 4 & 2.0 \\
\hline Sacrifice/rituals & 2 & 1.0 \\
\hline Social/cultural function & 3 & 1.5 \\
\hline Saving & 2 & 1.0 \\
\hline Risk/benefit & 24 & 12.0 \\
\hline Others & 2 & 1.0 \\
\hline Total & 200 & 100.0 \\
\hline
\end{tabular}

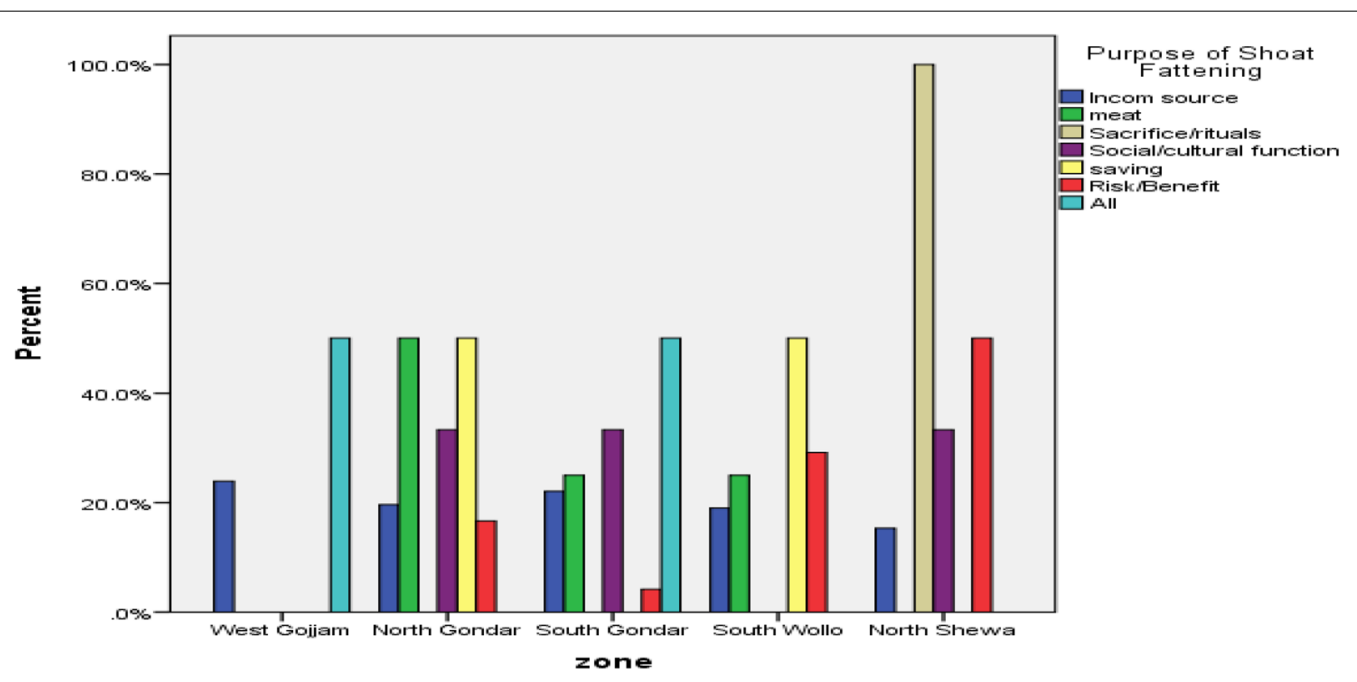

Fig. 5 Purpose of sheep and goat fattening in the study zones 
Table 7 The major feed sources in the dry and wet seasons for small ruminants in the study area

\begin{tabular}{llll}
\hline No. & Feed sources & Ranking \\
\cline { 3 - 4 } & & Wet season & Dry season \\
\hline 1 & Natural pasture & 1 & 2 \\
2 & Crop residue & 2 & 3 \\
3 & Grass hay & 5 & 5 \\
4 & Fodder tree & 3 & 6 \\
5 & Agro-industrial by-product & 4 & 4 \\
6 & Stubble grazing & 6 & 1 \\
7 & By-product of Millhouse & 7 & 7 \\
\hline
\end{tabular}

area showed that $48 \%$ of fatteners utilized crop residue and grass hay with supplements.

The study was in line with the result of [5]. In Ilu Aba Bora zone, the major sources of feed for small ruminants were natural pasture grazing and browsing on communal grazing lands, road and riverside and aftermath grazing.

Supplementary feed utilized for fattening is shown in Table 8. According to the respondents and direct observed of the farms in the study zones showed that fatteners formulate the rations without the background of scientific ration formulation or without the assistant of expertise. This might affect the fatteners exposed to extra feed cost and labor, over- and under-feeding and delay time of fattening.

Supplementary feeding practices of households in the study area are indicated in Table 9. Majority of fatteners (36\%) were provided with the formulated ration twice a day. However, the remaining were provided with the supplemented feed once in a day (31\%), whenever available (21\%) and three times a day (12\%) because according to the respondents it was because of expensive (77.6\%), not

\section{Table 8 Supplementary feed utilized for fattening}

\begin{tabular}{|c|c|c|}
\hline No. & Zones & Feed resources and ingredients \\
\hline 1 & West Gojjam & $\begin{array}{l}\text { Grass, straw, crop residue, surplus kitchen food, } \\
\text { Frusika, Fagulo, Atela (Birinte), salt }\end{array}$ \\
\hline 2 & North Gondar & $\begin{array}{l}\text { Frushica, Mashila, Fagulo, salt, surplus kitchen food, } \\
\text { corn, grinded meal by-product (Yewofcho Tiragi), } \\
\text { salt, Dashen brewery by-product }\end{array}$ \\
\hline 3 & South Gondar & $\begin{array}{l}\text { Crop residue, leaves, fodder trees, urea-treated } \\
\text { feed, salt }\end{array}$ \\
\hline 4 & South Wollo & $\begin{array}{l}\text { Alfalfa, Susbania, pigeon pea (Ye-ergib Ater), straw, } \\
\text { salt, grinded meal by-product (Yewofcho Tiragi), } \\
\text { straw, Fagulo, Frushica and Tree Lucerne }\end{array}$ \\
\hline 5 & North Showa & $\begin{array}{l}\text { Frushica, salt, local brewery by-product (Atela), } \\
\text { Vetch, grinded bean, bean bran, lentil bran, } \\
\text { barley bran, Fagulo, wilted and grinded Germia, } \\
\text { straw, salt, grinded barley, salt, wilted bean, } \\
\text { wilted Gerima }\end{array}$ \\
\hline
\end{tabular}

Table 9 Supplementary feeding in the study area

\begin{tabular}{lcr}
\hline Supplementary feeding & Frequency & $\%$ \\
\hline Frequency of supplementary feeding & & \\
Once in a day & 62 & 31.0 \\
Twice a day & 72 & 36.0 \\
Whenever available & 42 & 21.0 \\
Three times & 24 & 12.0 \\
Total & 200 & 100.0 \\
Reasons not providing supplementary feed scientifically recommended \\
Not available in the market & 38 & 19.4 \\
Expensive & 152 & 77.6 \\
No need of & 4 & 2.0 \\
Others & 2 & 1.0 \\
Total & 200 & 100.0 \\
\hline
\end{tabular}

available in the market (19.4\%), no need of (2\%) and others (1\%).

According to the report of [5] in Ilu Aba Bora zone, most of small ruminants were supplemented with concentrate feed whenever available. However, in the case of the present study the report was agreed. Fatteners were given supplementary feed twice a day. The reason supplementary feed was not given sufficiently for their small ruminants was its expensiveness in the market.

\section{Water sources and watering}

Water sources and watering for small ruminant fattening in the region are indicated in Table 10. In Amhara region, majority of small ruminant fatteners utilized water sources from pipe water (62.5\%), and the remaining 26.5, 5.5 and $5.5 \%$ got water from river, pond and spring water, respectively. During dry season, the average distance from home to the water source was less than $1 \mathrm{~km}(45 \%)$ and 23 and $32 \%$ of the respondents got water from with no distance and $1-5 \mathrm{~km}$, respectively.

The present study did not agree with the study of [5]. The major water sources in Ilu Aba bora zone for small ruminant production in the wet and dry seasons were rain and river. According to the study of [11] in West Shoa and South Wollo Zones, the major water sources in wet and dry seasons were river and river and tap water, respectively. Frequency of water in West Shoa and South Wollo was shown to be once in a day and once in 3 days in dry season, and twice a day and once in a day in wet season, respectively. 
Table 10 Water sources and watering for small ruminant fattening in the region

\begin{tabular}{lcl}
\hline Water sources & Frequency & $\%$ \\
\hline River & 53 & 26.5 \\
Pond & 11 & 5.5 \\
Spring water & 11 & 5.5 \\
Pipe water & 125 & 62.5 \\
Average distance of water from home to water sources during dry & \\
$\quad$ season & & \\
Water at home & 46 & 23 \\
$<1$ km & 90 & 45 \\
1-5 km & 64 & 32 \\
Watering frequency & & \\
Add libitum & 25 & 12.5 \\
Once in a day & 34 & 17 \\
Twice a day & 136 & 68 \\
Sometimes & 5 & 2.5 \\
\hline
\end{tabular}

\section{Conclusions}

In general, small ruminant fattening practices in Amhara region showed that majority of fatteners did not have a private grazing land for fattening purpose. The status of private and communal grazing lands shows a decreasing trend from time to time. This might be due to the increment of human population, the decline in the productivity of land, shifting of grazing land into crop land, the expansion of settlement, the increment of animal population and so on. In the region, producers were mostly involved in sheep fattening than goat fattening. The main purpose of fattening small ruminants in the region was used for income generation. The main feed sources in the wet and dry seasons were natural pasture and stubble grazing, respectively. In addition to this, the source of supplementary feeds was surplus kitchen food, wheat bran, nuge seed cake, maize or corn, Mashila, grinded meal by-product, pigeon pea, alfalfa, Susbania, Tree Lucerne, brewery by-product, local brewery by-product (Atela and Brinte), Vetch, grinded bean, wilted and grinded Gerima bean and lentil bran, salt, etc. Some of fatteners were also provided with these supplementary feeds twice a day. This was due to an expensiveness of the supplementary feeds in the market. The major water sources for small ruminants were rivers, and the average distance was less than one $\mathrm{km}$. Water frequency was twice a day. Based on the above information, the livestock and fishery ministry should implement the meat and feed improvement strategic plan, and universities and research institutes should conduct a research on feed improvement and fattening trial with low cost. Further research on alternative feeds for fattening of the abovelisted supplementary feeds on feed intake, body weight change and carcass yield as well as digestibility on sheep and goats in the region should be done. A policy for small ruminant fattening program should be given attention.

\section{Authors' contributions}

The corresponding author SA contributed to the conceptualization and methodology; formal analysis contributed to investigation and writing of the original draft; and SAM and AAT, AGE, MBA and ATS contributed to data curation, validation, writing, review and editing. All authors read and approved the final manuscript.

\section{Author details}

${ }^{1}$ University of Gondar, P.O. Box 196, Gondar, Ethiopia. ${ }^{2}$ Andassa Livestock Research Center, P.O. Box 77, Bahir Dar, Ethiopia.

\section{Acknowledgements}

We would like to thank University of Gondar for supporting this research project. We would like to thank the Amhara regional district and kebele experts for their collaboration of data collection and information. We would like to also thank small ruminant fatteners in the Amhara region for their great collaboration of information sharing.

\section{Competing interests}

The authors declare that we have no competing interests.

\section{Availability of data and materials}

It is possible to access the data on personnel request from the principal investigator

\section{Consent for publication}

Consent was taken from the regional small ruminant fatteners.

\section{Ethics approval and consent to participate}

The study was undertaken after the approval of the institutional research ethical review committee of University of Gondar.

\section{Funding}

This research was supported by funding from University of Gondar.

\section{Publisher's Note}

Springer Nature remains neutral with regard to jurisdictional claims in published maps and institutional affiliations.

Received: 21 July 2018 Accepted: 5 September 2018

Published online: 12 September 2018

\section{References}

1. ACDINOCA. Djibouti Study Tour-Trip Report. ACDINOCA Pastoralist Livelihoods Initiative Livestock Marketing Program. 26-28 Aug 2008. p. 12. https://www.guidestar.org/NiewEdoc.aspx?eDocld=3194250\&appro ved $=$ True.

2. Berhanu G, Hoekstra D, Azege T. Improving the competitiveness of agricultural input markets in Ethiopia: experiences since 1991. Paper presented at the symposium on seed-fertilizer technology, cereal productivity and pro-poor triennial conference of the International Association of Agricultural Economics (IAAE), Gold Coast, Australia; 2006. https://cgspa ce.cgiar.org/bitstream/handle/10568/.../improvingCompetitiveness.pdf?

3. CSA (Central Statistics Agency). Agricultural Sample. Addis Ababa, Ethiopia; 2005. www.csa.gov.et/monthly-retail-price/category/121-eth-agss2005?download...2005

4. CSA (Central Statistics Agency). Agricultural sample survey 2014/15. Volume II report on livestock and livestock characteristics (Private Peasant Holdings), Central Statistical Agency (CSA), Addis Ababa, Ethiopia; 2015. p. 188. www.csa.gov.et/ehioinfo-internal/category/131-eth-agss2015? download=397.

5. Dhaba U, Belay D, Solomon D and Taye T. Breeding practices and reproductive performance of traditionally managed indigenous sheep and 
goat in Ilu Abba Bora Zone of Oromia Regional State, Ethiopia; 2013. p 676-80. https://doi.org/10.5829/idosi.gv.2013.10.6.64163.

6. Jainter J, Sowe J, Secka NE, Dempfle L. Ownership pattern and management practices of small ruminants in the Gambia-implications for a breeding programme. Small Rumin Res. 2001;40:101-8.

7. Kefyalew A, Tarekegn A. Meat and live animal export in Ethiopia: status, challenges and opportunities; 2013. p. 054-9.

8. Mueller B, Acero F, Estruch E. Creating employment potential in smallruminant value chains in the Ethiopian Highlands. FAO Animal production and health working paper no. 16, Rome, FAO; 2017. http://www.fao. org/ag/againfo/resources/en/publications.html.

9. Pelant RK, Chandra B, Pu JB, Lohani M, Suknaphasawat N, Xu G. Small ruminants in development. Small Rumin Res. 1999;34(3):249-57. https:// doi.org/10.1016/s0921-4488(99)00077-2.

10. Solomon G, Azage T, Berhanu G and Dirk H. Sheep and goat production and marketing systems in Ethiopia: characteristics and strategies for improvement. IPMS (improving productivity and market success) of Ethiopian farmers project working paper 23. ILRI (International Livestock
Research Institute), Nairobi, Kenya; 2010. p. 58. https://cgspace.cgiar.org/ bitstream/handle/10568/2238/IPMS_Working_Paper_23.pdf.

11. Trevor AC. Advancing Ethiopian small ruminant production systems. Borlaug-Ruan International Intern World Food Prize International Livestock Research Institute Addis Ababa, Ethiopia. https://www.worldfoodprize. org/documents/filelibrary/images/youth_programs/2015_interns/2015_ br_research_papers/Clemens_ILRI_Ethiopia_FinalReport_7C63C2512D 16D.pdf. Accessed 17-18 Dec 2015.

12. USAID. End market analysis of Ethiopian livestock and meat. A desk study micro report\#164. https://www.bdsknowledge.org/dyn/bds/docs/801/ USAID. Accessed May 2010

13. Yenesew A. Assessment of small ruminant production systems and onfarm evaluation of urea treated wheat straw and concentrate feeding on sheep body weight change in Burie Woreda, West Gojjam; 2010. https:// cgspace.cgiar.org/handle/10568/792.
Ready to submit your research? Choose BMC and benefit from:

- fast, convenient online submission

- thorough peer review by experienced researchers in your field

- rapid publication on acceptance

- support for research data, including large and complex data types

- gold Open Access which fosters wider collaboration and increased citations

- maximum visibility for your research: over $100 \mathrm{M}$ website views per year

At BMC, research is always in progress.

Learn more biomedcentral.com/submissions 